\title{
Plasmid Mediated Quinolone Resistance Determinants among Nosocomial Clinical Pseudomonas aeruginosa Isolates
}

\author{
Mohammed A. Saleh ${ }^{1 *}$ and Mohammed M. Balboula ${ }^{2}$ \\ ${ }^{1}$ Department of Microbiology and Immunology, Faculty of Medicine, Al-Azhar University, \\ New Damietta, Egypt \\ ${ }^{2}$ Department of General Surgery, Faculty of Medicine, Al-Azhar University, \\ New Damietta, Egypt \\ *Corresponding author
}

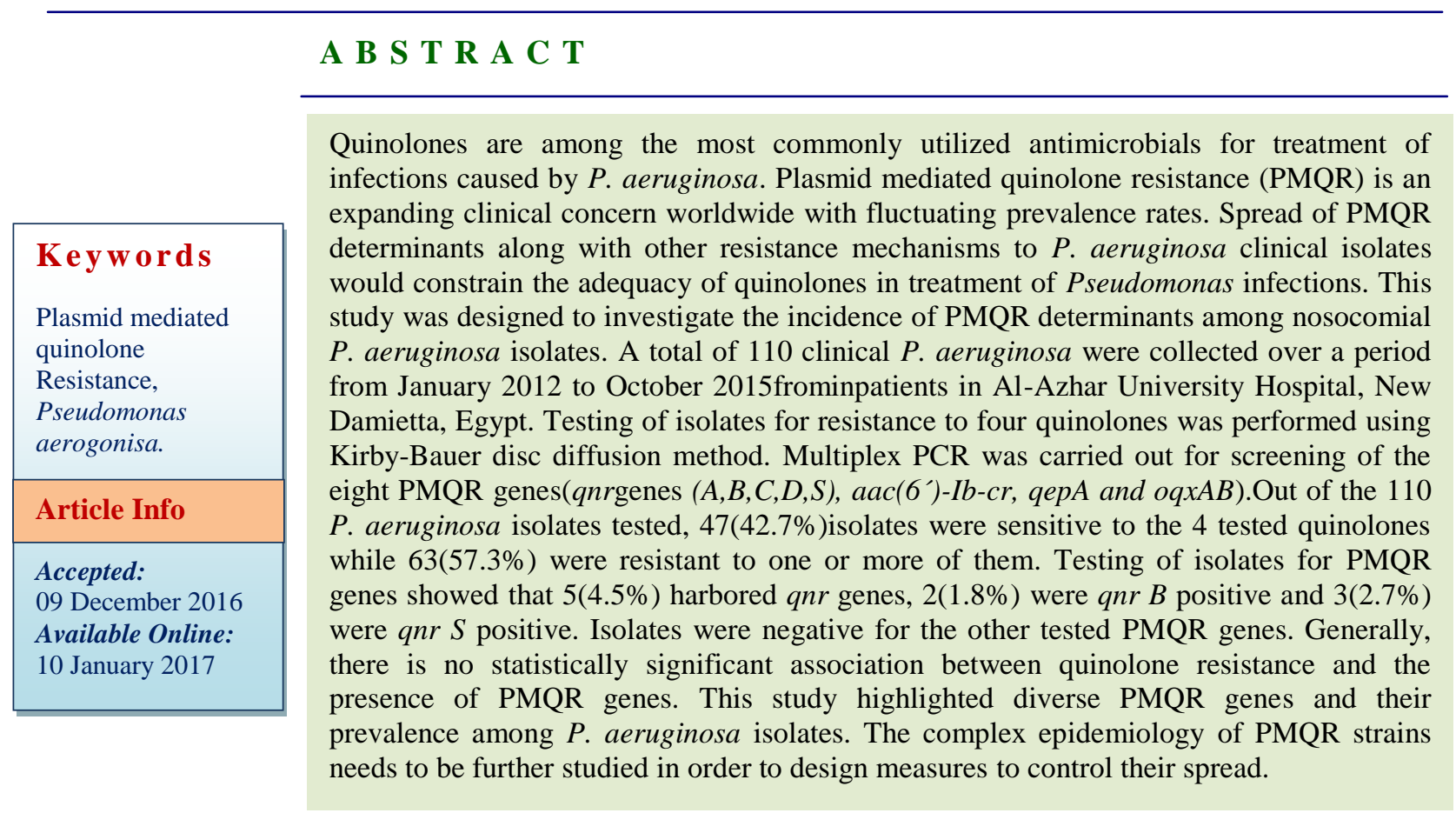

\section{Introduction}

Pseudomonas aeruginosa ( $P$. aeruginosa) is a Gram-negative bacterium that inhabits a wide scope of environmental and pathogenic habitats. It has the capacity to cause extremely different acute and chronic infections (Hancock, 1998). It has been involved in diverse nosocomial infections including, pneumonia, blood stream infection, urinary tract infection, surgical site infection and burn wounds infection infection (Anuradha et al., 2014). It is accountable for about $10-20 \%$ of nosocomial infections (Carmeli et al., 2002).

Quinolones are broad-spectrum antimicrobial agents that are widely utilized in both medical 
and veterinary practice. They are the most effective antibiotics for oral treatment of $P$. aeruginosa infections in most countries (ALMarjani, 2014).

However, the efficacy and resulting widespread use of quinolones have prompted a consistent worldwide increase in resistance (Guan et al., 2013). Antibiotic resistance is a significant and mounting hurdle to the treatment and management of microbial disease (Wong and Kassen, 2011). The subsequent increase in quinolone resistance is currently undermining the clinical utility for various infections (Kim and Hooper, 2014).In particular, resistant $P$. aeruginosa infections are associated with adverse outcomes such as high mortality, morbidity, and expanded costs (Nathwaniet al., 2014).

Quinolones act by inhibiting the bacterial enzymes DNA gyrase and topoisomerase IV. Such formation of drug-enzyme-DNA complexes blocks DNA replication. Bacterial resistance to quinolones mainly is chromosomal-mediated including, mutations in the quinolone resistance determining regions (QRDRs) of DNA gyrase and topoisomerase IV, efflux pumps enhancement or decreased accumulation as a result of decreased permeability of bacterial cell wall (Azadpour et al., 2014).

Multiple studies demonstrated that quinolone resistance can be also intervened by plasmidcarried genes. In 1998, plasmid mediated quinolone resistance (PMQR) was initially reported in a Klebsiella pneumonia in clinical isolates (Hooper, 1998). From that point forward, the causal mechanisms of resistance have been illustrated. Three mechanisms of PMQR were identified which are mediated by $q n r$ genes (coding Qnr proteins), $a a c\left(6^{\prime}\right)-I b$ $c r$, qepA and oqxAB genes (Kulková et al., 2014).
Martínez-Martínez and colleagues reported the first PMQR mechanism which is mediated by $q n r$ genes in 1998 (Martínez-Martínez et al., 1998). So far, five $q n r$ genes were recognized ( $q n r A, B, S, C$ and $D$ ) which encode Qnr proteins that inhibit quinolones binding to their bacterial targets (Kulková et al., 2014, Azadpour et al., 2014, Alheib et al., 2015). These qnr genes best owa low resistance level to quinolones, however, it supportsthe selection of chromosomal mutations resulting in resistance development in the host strain (Martinez et al., 1998).

The second PMQR mechanism was distinguished in 2006, which is interceded by aac (6')-Ib-crgene that encodesamino glycoside acetyltransferase which acetylate aminoglycosides as well asciprofloxacin and norfloxacin (Robicsek et al., 2006). Nevertheless, aac(6')-Ib-cr contributes just to small increase in MIC levels (Poirelet al., 2012).

The third PMQR mechanism, the active efflux, is intervened by two genes that encode quinolone transporters QepA and OqxAB which pump the drug out of the bacterial cell (Hansen et al., 2007 and Yamane et al., 2007).

Recently, a multiplex PCR assay for eight PMQR genes has been achieved (Ciesielczuk et al., 2013).

PMQR determinants have been distinguished globally in many Gram-negative bacteria particularly Enterobacteriaceae family with variable frequency but they have not been examined in $P$. aeruginosa isolates except in small number of studies. As PMQR determinants are not taken into account in resistance screening by microbiological laboratories, this study was aimed to assess the prevalence of the eight genes ( $q n r A, B, S$, $C, D, a a c\left(6^{\prime}\right)-I b-c r, q e p A$ and oqxAB) that 
confer PMQR among nosocomial $P$. aeruginosa isolates obtained from clinical samples collected from patients admitted to Al-Azhar University Hospital, New Damietta, Egypt.

\section{Methods}

\section{Study design and participants}

This prospective study was carried out over a period from January2012 to October 2015. It included $110 P$. aeruginosa isolates recovered from 675 different clinical specimens collected from inpatients admitted to AlAzhar University Hospital, New Damietta, Egypt and showing symptoms and signs of nosocomial infections in various body sites.

\section{Collection of samples and microbiological examination}

Different clinical samples were collected from nosocomially-infected patients and cultured on cetrimide and MacConky agar (Oxoid, England). Identification of $P$. aeruginosa isolates was carried out according to the standard microbiological methods including, colonial morphology, Gram stain, biochemical reactions and ability of growth at $42^{\circ} \mathrm{C}$ (Koneman et al., 2006).

\section{Antibiotic susceptibility testing}

To identify quinolone resistance among $P$. aeruginosa isolates, Kirby-Bauer disc diffusion technique was carried out on Muller-Hinton agar (Oxoid, England) according to Clinical Laboratory Standard Institute (CLSI) guidelines, 2012 using commercially available discs including, ciprofloxacin $(5 \mu \mathrm{g})$, Ofloxacin $(5 \mu \mathrm{g})$, norfloxacin $(10 \mu \mathrm{g})$, and levofloxacin $(5 \mu \mathrm{g})$ discs (Oxoid, England). Isolates which showed intermediate susceptibility were considered as resistant.

\section{Multiplex PCR for PMQR determinants genes detection}

DNA preparation was performed through a boiling technique. Freshly obtained $P$. aeruginosa colonies were transferred in 500 $\mu \mathrm{l}$ sterile distilled water and incubated at $100^{\circ} \mathrm{C}$ for 20 minutes. Then, the bacterial solution was centrifuged at $15000 \mathrm{~g}$ for 20 min in order to obtain a supernatant that was subsequently used as template DNA (Azadpour et al., 2014). PCR for the eight PMQR genes was performed using the Multiplex PCR kit (Qiagen, Germany). PMQR primers and thermocycling conditions used were designed as described previously by Ciesielczuk et al., 2013. Primers used are listed in Table 1. Thermocycling conditions were as follow: initial denaturation at $95{ }^{\circ} \mathrm{C}$ for 15 minutes; 30 cycles of $94{ }^{\circ} \mathrm{C}$ for 30 seconds, $63{ }^{\circ} \mathrm{C}$ for 90 seconds and $72{ }^{\circ} \mathrm{C}$ for 90 seconds; followed by a final extension at $72^{\circ} \mathrm{C}$ for $10 \mathrm{~min}$. Amplification products were detected by gel electrophoresison $2 \%$, ethidium bromide stained agarose gels at 130 $\mathrm{V}$ for $2 \mathrm{~h}$ against $100 \mathrm{bp}$ ladder DNA marker.

\section{Statistical analysis}

Ranges and percentages were used as descriptive statistics. Chi-square analysis was employed to validate correlation between PMQR determinants and resistance to quinolones. All statistical analyses were performed using Statistical Package for Social Science program (SPSS version 15.0 for windows, Chicago, IL). $\mathrm{P}<0.05$ was considered statistically significant.

\section{Ethical approval}

The study protocol was reviewed and approved by the local ethical committee of Faculty of Medicine, Al-Azhar University, New Damietta, Egypt. 


\section{Results and Discussion}

This study included $110 \quad P$. aeruginosa isolates $(16.2 \%)$ recovered from 675nosocomial clinical samples collected from various body sites. The distribution of $P$. aeruginosa isolates in relation to type of clinical sample are shown in Table 2. The highest rate of isolation was from endotracheal tube secretions (ETT)(24.3\%) and the least from urine samples (13.4\%). Out of the $110 P$. aeruginosa isolates, 47 $(42.7 \%)$ were sensitive to the four tested quinolones while $63(57.2 \%)$ were resistant to one or more of them. Considering isolates which showed intermediate susceptibility as resistant, the results of quinolone susceptibility testing showed that the resistance rates against tested quinolones varied from $16.3 \%$ to $35.4 \%$ as demonstrated in Table3.

Screening of the tested $P$. aeruginosa isolates for PMQR genes revealed that 5(4.5\%) were harboring $q n r$ genes; $2(1.8 \%)$ were $q n r B$ positive and 3(2.7 \%) were $q n r$ Spositive (Table 4). One $q n r B$ positive isolate $(2.1 \%)$ was from the 47 quinolone- sensitive isolates while the other 4qnrpositiveisolates (6.3\%)were among the 63 quinolone-resistant isolates.

Interestingly, there is no statistically significant association between the presence of $q n r$ genes and quinolone resistance $\left(\mathrm{X}^{2}=\right.$ $0.97, \mathrm{P}$ value $=0.32)$. Neither other $q n r$ genes, aac (6')-Ib-cr, qepA nor oqxAB gene was detected in our study isolates.

Currently, $P$. aeruginosa is not only one of the most frequent nosocomial pathogens and but also represent a challenge to treatment due to its antibiotic resistance (Daini and CharlesOnyeaghala, 2012). This study showed that nosocomial $P$. aeruginosa clinical isolates was recovered from tested clinical specimens at a rate of $16.2 \%$. This is in agreement with Gad et al., 2007 and Mahmoud et al., 2013 who reported rate of $18 \%$ and $19 \%$ respectively.

The highest isolation rate of $P$. aeruginosa was encountered from ETT secretions (24.3\%). Similarly, Khosravi et al., 2012reported $P$. aeruginosa as the second most prevalent organism isolated from ETT secretions. However, other studies isolated the highest number of $P$. aeruginosa infection from pus samples (Anuradha et al., 2014) and urine (Bashir et al., 2011).

Evaluation of the efficacy of the quinolones used in this study against $P$. aeruginosa clinical isolates revealed that more than half of the isolates $(57.2 \%)$ were resistant to one or more of the tested antibiotics. This signifies a real warning in light of the fact that widespread, irrational and inappropriate administration of antibioticis responsible for resistance.

In our investigation, the most effective drug against $P$. Aeruginosa was Levofloxacin followed by Ofloxacin then Ciprofloxacin and lastly Norfloxacin with resistance rates $18 \%$, $25 \%, 28 \%$ and $40 \%$ respectively. These data are coordinated with that that of Akingbade $e t$ al., 2012 which indicated that Levofloxacin was the most potent quinolone used against $P$. aeruginosa. Ofloxacin, however, was the best quinolone, according to Nwanze et al., 2007, while Idu and Odjiimogho, 2003 found that Ciprofloxacin is the most efficient one. These disparities in sensitivity pattern could be attributed to that provincial differences that possibly play a role in the resistance profile of bacteria and further supports the necessity to regularly perform antibiotic susceptibility testing on bacterial isolates from various locales. In spite of the fact that PMQR determinants have been investigated in many countries around the world, there is only a small number of reports on frequency of 
PMQR determinants among $P$. Aeruginosa isolates. To our best knowledge, this is the first study to evaluate the eight PMQR genes together among nosocomial $P$. aeruginosa isolates obtained from different clinical samples.
Screening of the eight PMQR genes in this work, revealed that qnr $B$ and qnr $S$ genes were infrequently detected in only $2(1.8 \%)$ and $3(2.7 \%)$ of the tested isolates respectively.

Table.1 Primers for amplification of PMQR molecular determinants

\begin{tabular}{|l|l|l|}
\hline \multicolumn{1}{|c|}{ PMQR gene } & \multicolumn{1}{c|}{ Primersequence 5' to3' $^{\prime}$} & \multicolumn{1}{c|}{ size of amplicon (bp) } \\
\hline$q n r A$ & $\begin{array}{l}\text { F: 5'- CAGCAAGAGGATTTCTCACG-3' } \\
\text { R:5'- AATCCGGCAGCACTATTACTC-3' }\end{array}$ & 630 \\
\hline $\begin{array}{l}q n r B \\
\text { (degenerate) }\end{array}$ & $\begin{array}{l}\text { F:5-' GGCTGTCAGTTCTATGATCG-3' } \\
\text { R:5'- GAGCAACGATGCCTGGTAG-3' }\end{array}$ & 488 \\
\hline$q n r S$ & $\begin{array}{l}\text { F: 5'- GCAAGTTCATTGAACAGGGT-3' } \\
\text { R:5'- TCTAAACCGTCGAGTTCGGCG-3' }\end{array}$ & 428 \\
\hline oqxAB & $\begin{array}{l}\text { F: 5'- CCGCACCGATAAATTAGTCC-3' } \\
\text { R:5'- GGCGAGGTTTTGATAGTGGA-3' }\end{array}$ & 313 \\
\hline$q a c(69)-$-Ib-cr & $\begin{array}{l}\text { F: 5'- TTGGAAGCGGGGACGGAM-3' } \\
\text { R:5'- ACACGGCTGGACCATA-3' }\end{array}$ & 260 \\
\hline$q e p A$ & $\begin{array}{l}\text { F: 5'- GCAGGTCCAGCAGCGGGTAG-3' } \\
\text { R:5'- CTTCCTGCCCGAGTATCGTG-3' }\end{array}$ & 218 \\
\hline$q n r C$ & $\begin{array}{l}\text { F: 5'- GCAGAATTCAGGGGTGTGAT-3' } \\
\text { R:5'- AACTGCTCCAAAAGCTGCTC-3' }\end{array}$ & 118 \\
\hline$q n r D$ & $\begin{array}{l}\text { F: 5'- CGAGATCAATTTACGGGGAATA-3' } \\
\text { R:5'- AACAAGCTGAAGCGCCTG-3' }\end{array}$ & 581 \\
\hline
\end{tabular}

Abbreviations:bp: base-pairs;

Table.2 Distribution of P.aeruginosa isolates in relation to type of clinical sample

\begin{tabular}{|c|c|c|c|}
\hline \multicolumn{2}{|c|}{ Clinical samples } & \multicolumn{2}{c|}{ P.aeruginosa isolates } \\
\hline Type & No. & No. & $\%$ \\
\hline Wound swab & 175 & 39 & 22.2 \\
\hline Urine & 171 & 23 & 13.4 \\
\hline Blood & 108 & 17 & 15.7 \\
\hline Sputum & 107 & 21 & 14.6 \\
\hline $\begin{array}{c}\text { Endotracheal tube } \\
\text { secretions(ETT) }\end{array}$ & 41 & 10 & 24.3 \\
\hline Pleural fluid & 10 & 0 & 0 \\
\hline Stool & 31 & 0 & 0 \\
\hline Ascitic fluid & 32 & 0 & 0 \\
\hline Total & 675 & 110 & 16.2 \\
\hline
\end{tabular}


Table.3 Quinolone resistance among P.aeruginosa isolates

\begin{tabular}{|l|c|c|c|c|c|c|}
\hline \multirow{2}{*}{ Quinolone } & \multicolumn{2}{|c|}{ Resistant isolates } & \multicolumn{2}{c|}{$\begin{array}{c}\text { Intermediately } \\
\text { susceptible isolates }\end{array}$} & \multicolumn{2}{c|}{ Susceptible isolates } \\
\cline { 2 - 7 } & No & $\%$ & No & $\%$ & No & $\%$ \\
\hline Norfloxacin & 37 & 33.6 & 3 & 2.7 & 70 & 63.7 \\
\hline Ciprofloxacin & 26 & 23.6 & 2 & 1.8 & 82 & 74.6 \\
\hline Ofloxacin & 24 & 21.8 & 1 & 0.9 & 85 & 77.3 \\
\hline Levfloxacin & 16 & 14.5 & 2 & 1.8 & 92 & 83.7 \\
\hline
\end{tabular}

Table.4 Characteristics of PMQR genes positive P.aeruginosa isolates

\begin{tabular}{|c|c|c|c|c|c|c|c|c|}
\hline \multirow{2}{*}{$\begin{array}{l}\text { Isolate } \\
\text { No. }\end{array}$} & \multirow{2}{*}{$\begin{array}{l}\text { PMQR } \\
\text { gene }\end{array}$} & \multirow{2}{*}{$\begin{array}{l}\text { Patient } \\
\text { age } \\
\text { (years) }\end{array}$} & \multirow{2}{*}{$\begin{array}{l}\text { Patient } \\
\text { gender }\end{array}$} & \multirow{2}{*}{$\begin{array}{l}\text { Isolate } \\
\text { source }\end{array}$} & \multicolumn{4}{|c|}{ Quinolone sensitivity } \\
\hline & & & & & Norfloxacin & Ciprofloxacin & Ofloxacin & Levfloxacin \\
\hline 1 & $q n r B$ & 45 & Male & Wound & $S$ & $S$ & $S$ & $S$ \\
\hline 2 & $q n r B$ & 33 & Male & Wound & $\mathrm{R}$ & $\mathrm{R}$ & $S$ & $S$ \\
\hline 3 & $q n r S$ & 51 & Male & Wound & $\mathrm{S}$ & $\mathrm{S}$ & $\mathrm{I}$ & $\mathrm{R}$ \\
\hline 4 & $q n r S$ & 30 & Female & Urine & $\mathrm{R}$ & $\mathrm{S}$ & $\mathrm{R}$ & $\mathrm{S}$ \\
\hline 5 & $q n r S$ & 61 & Male & ETT & $\mathrm{R}$ & $\mathrm{S}$ & $\mathrm{R}$ & $S$ \\
\hline
\end{tabular}

S: sensitive I: intermediate susceptibility R: resistant ETT: Endotracheal tube secretions

These findings were lower than the two previously conducted studies carried out by Michalska et al., 2014 who reported the presence of $q n r$ B in $20 \%$ of isolates recovered in Northeastern, Poland and AlMarjani et al., 2014 who detected $q n r S$ in $21 \%$ of isolates in Bagdad, Iraq. Other studies failed to detect $q n r B$ or $q n r S$ genes among the examined isolates (Shin et al., 2009, Xueqing et al., 2014, Cayci et al., 2014).

Consequently, detection of $q n r$ genes in our study might be potentially indicative of a rising pattern in the predominance rate of PMQR genes among isolates in Egypt.

Other $q n r$ genes (A, C, D), $a a c\left(6^{\prime}\right)-I b-c r$, qepA and oqxABgenes were not identified in our study, in concordance with the results verifiedin other literatures (Shin et al., 2009, Jafari et al., 2013, Xue-qing et al., 2014, Michalska et al., 2014, Cayci et al., 2014, Wong et al., 2015). Other investigators revealed the presence of $a a c\left(6^{\prime}\right)-I b-c r$ gene
(Poole, 2011), qnr A gene (Al-Marjani, 2014) among their studied isolates.

In this analysis, quite there was no statistically significant correlation between presence of $q n r$ determinants and quinolone resistance $(\mathrm{P}=0.32)$. Our finding concurs with other reports showing that $q n r$ determinants alone does not grant resistance to quinolones, however its presence may accelerate selection of additional chromosomal mutations. Therefore, using quinolone resistance as marker for detection may under value the predominance of $q n r$ determinants, which provokes concern for the undetected extent of these genes (Alheib et al., 2015).

In conclusion, quinolone resistance is a public health issue, bearing in mind their widespread prevalence on one side and the extending resistance by plasmids on the other side. This investigation constitutes the first epidemiological survey of the eight PMQR determinants among $P$. aeruginosa isolates. 
Emergence of $q n r B$ and $S$ genes in our study isolates may participate to development and spread of quinolone resistance, hence, judicious use of antibiotic and adjusted treatment protocols represent a necessity. These data highlight the obligation for screening of $P$. aeruginosa for PMQR determinants in hospital settings in further studies with larger number of isolates and broader geographic distribution to determine the widespread distribution of PMQR determinants and estimate the extent of the problem.

\section{References}

Akingbade, O., Balogun, S., Ojo, D., Afolabi, R., Motayo, B., Okerentugba, P., et al. 2012. Plasmid profile analysis of multidrug resistant Pseudomonas aeruginosa isolated from wound infections in South West, Nigeria. World Appl. Sci. J., 20(6): 766775 .

Alheib, O., Al Kayali, R., and Abajy, M.Y. 2015. Prevalence of Plasmid-Mediated Quinolone Resistance (PMQR) Determinants Among Extended Spectrum Beta-Lactamases (ESBL)Producing Isolates of Escherichia coli and Klebsiella pneumoniae in Aleppo, Syria. Arch. Clin. Infect. Dis., 10(3): e20631.

AL-Marjani, M.F. 2014. Presence of $q n r$ gene in Environmental and Clinical Pseudomonasaeruginosa isolates in Baghdad. Int. J. Curr. Microbiol. App. Sci., 3(7): 853-857.

Anuradha, B., Afreen, U., and Praveena, M. 2014. Evaluation of Antimicrobial susceptibility pattern of Pseudomonas aeruginosa with special reference to MBL production in a tertiary care hospital. Global J. Med. Res., 14: 22-28.

Azadpour, M., Soleimani, Y., Rezaie, F., Nikanpour, E., Mahmoudvand, H., and
Jahanbakhs, S. 2014. Prevalence of $q n r$ Genes and Antibiotic Susceptibility Patterns among Clinical Isolates of Klebsiella Pneumoniae in West of Iran. J.Bacteriol. Parasitol., 5(5): 1-4.

Bashir, D., Thokar, M.A., Fomda, B.A., Bashir, G., Zahoor, D., Ahmad, S., and Abubaker, S.T. 2011. Detection of Metallo-beta-lactamase

(MBL) producing Pseudomonas aeruginosa at a tertiary care hospital in Kashmir. African J. Microbiol. Res., 5(2): 164172.

Carmeli, Y., Eliopoulos, G.M., and Samore, M.H. 2002. Antecedent treatment with differentantibiotic agents as a risk factor for vancomycin-resistant Enterococcus. Emerg. Infect. Dis., 8: 802-807.

Cayci, Y.T., Coban, A.Y., Gunaydin, M. 2014. Investigation of plasmid-mediated quinolone resistance in Pseudomonas aeruginosa clinical isolates. Ind. J. Med. Microbiol., 32(3): 285-289.

Ciesielczuk, H., Hornsey, M., Choi, V., Woodford, N., and Wareham, D.W. 2013. Development and evaluation of a multiplex PCR for eight plasmidmediated quinolone-resistance determinants. J. Med. Microbiol., 62: 1823-1827.

Clinical and Laboratory standards institute (CLSI). 2012. Performance standards for antimicrobial susceptibility testing CLSI document M100-S18.

Daini, O.A., and Charles- Onyeaghala, C.G. 2012. Plasmid- mediated aminoglycoside resistance of clinical isolates of pseudomonas aeruginosa. Glo. Adv. Res. J. Microbiol., 1(4): 5256.

Gad, G.F., El- Domany, R.A., Zaki, S., and Ashour, H.M. Characterization of Pseudomonas Aeruginosa Isolated from Clinical and Environmental Samples in Minia, Egypt: Prevalence, Antibiogram and Resistance Mechanisms. $J$. 
Antimicrob. Chemother., 60: 10101017.

Guan, X., Xue, X., Liu, Y., Wang, J., Wang, Y., Wang, K., Jiang, H., Zhang, L., Yang, B., Wang, N., and Pan L. 2013. Plasmid mediated quinolone resistancecurrent knowledge and future perspectives. J. Int. Med. Res., 41: 20-30.

Hancock, R.E.W. 1988. Resistance mechanisms in Pseudomonas aeruginosa and other nonfermentative gram-negative bacteria. Clin. Infect. Dis., 27Suppl 1, S93-99.

Hansen, L.H., Jensen, L.B., Sorensen, H.I., and Sorensen, S.J. 2007. Substrate specificity of the OqxAB multidrug resistance pump in Escherichia coli and selected enteric bacteria. J. Antimicrob. Chemother., 60:145-147.

Hooper, D.C. 1998. Bacterial topoisomerases, anti-topoisomerases, and antitopoisomerase resistance. Clin. Infect. Dis., 27Suppl 1, S54-S63.

Idu, F.K., and Odjimogho, S.E. 2003. Susceptibility of conjunctival bacterial pathogens to flouroquinolones: A comparative study of ciprofloxacin, norfloxacin and Ofloxacin. Online $J$. Health and App. Sci., (OJHAS): 2(3).

Jafari, M., Fallah, F., Borhan, R.S., Navidinia, M., Karimi, A., Hashemi, A, et al. 2013. The First Report of CMY, aac (6')-Ib and 16S rRNA Methylase Genes Among Pseudomonas aeruginosa Isolates From Iran. Arch. Pediatr. Infect. Dis., 1(3):109-112.

Khosravi, Y., Loke, M.F., Chua, E.G., Tay, S.T., and Vadivelu, J. 2012. Phenotypic detection of metallo-beta-lactamase in imipenem-resistant Pseudomonas aeruginosa. Sci. World J., doi:10.1100/2012/654939.

Kim, E.S., and Hooper, D.C. 2014. Clinical importance and epidemiology of quinolone resistance. Infect.
Chemother., 46, 226-238.

Koneman, E., Winn, W. J., Allen, S., Janda, W., Procop, G., Woods, G., and Schreckenberger, P. 2006. Chapter 7: The Nonfermentative Gram-Negative Bacilli, pp. 264-269. In Koneman's Color Atlas and Textbook of Diagnostic Microbiology, $\quad\left(6^{\text {th }} \quad\right.$ ed.): 2006. Lippincott Williams and Wilkins, London.

Kulková, N., Babálová, M., Brnová, J., and Krcméry, V. 2014. Transferable quinolone resistance in Enterobacteriaceae and Pseudomonas aeruginosa isolated from Hemocultures short communication. Cent. Eur. J. Public Health, 22(1): 60-63

Mahmoud, A.B., Zahran, W.A., Hindawi, G.R., Labib, A.Z. and Galal R. 2013. Prevalence of Multidrug-Resistant Pseudomonas aeruginosa in Patients with Nosocomial Infections at a University Hospital in Egypt, with Special Reference to Typing Methods. J. Virol. Microbiol., 1-13.

Martinez, J.L., Alonso, A., Gomez-Gomez, J.M. et al. 1998. Quinolone resistance by mutations in chromosomal gyrase genes Just the tip of the iceberg? $J$. Antimicrob. Chemother., 42, 683-688.

Martínez-Martínez, L., Pascual, A., and Jacoby, G.A. 1998. Quinolone resistance from a transferable plasmid. Lancet, 351: 797-799.

Michalska, A.D., Sacha, P.T., Ojdana, D., Wieczorek, A., and Tryniszewska, E. 2014. Prevalence of resistance to aminoglycosides and fluoroquinolones among Pseudomonas aeruginosa strains in a University Hospital in Northeastern Poland. Brazil. J. Microbiol., 45(4): 1455-1458.

Nathwani, D., Raman, G., Sulham, K., Gavaghan, M, and Menon, V. 2014. Clinical and economic consequences of hospital-acquired resistant and 
multidrug-resistant Pseudomonas aeruginosa infections: a systematic review and meta-analysis. Antimicrob. Resist. Infect. Contr., 3: 32-48.

Nwanze, P.I., Nwaru, L.M., Oranusi, S., Dimkpa, U., Okwu, M.U., Babatunde, B.B., Anake, T.A., Jatto, W., and Asagwara, C.E. 2007. Urinary tract infection in Okada village: Prevalence and antimicrobial susceptibility pattern. Scient. Res. Essay, 2; 112-116.

Poirel, L., Cattoir, V., and Nordmann, P. 2012. Plasmid-mediated quinolone resistance; interactions between human, animal, and environmental ecologies. Front. Microbiol., 3: 96-102.

Poole, K. 2011. Pseudomonas aeruginosa: resistance to the max. Front. microbial., 2: 65

Robicsek, A., Strahilevitz, J., Jacoby, G.A., Macielag, M., Abbanat, D., Park, C.H., Bush, K., and Hooper, D.C. 2006. Fluoroquinolone-modifying enzyme: a new adaptation of a common aminoglycoside acetyl transferase. Nat. Med. 12; 83-88.

Shin, J.H., Jeong, H.S., Jung, H.J., Kim, S.H., Lee, J.Y., $\quad$ Oh, S.H., Kim, H.R., Lee, J.N., Bae, I.K., and Chang, C.L. 2009. Prevalence of plasmid-mediated quinolone resistance and its association with extended-spectrum $\beta$ - lactamase in clinical isolates from Korea. 19th European Congress of Clinical Microbiology and Infectious Diseases, Helsinki, Finland.

Wong, A., and Kassen, R. 2011. Parallel evolution and local differentiation in quinolone resistance in Pseudomonas aeruginosa. Microbiol., 157, 937-44.

Wong, M.H.Y., Chan, E.W.C., and Chena, S. 2015. Evolution and Dissemination of OqxAB-Like Efflux Pumps, an Emerging Quinolone Resistance Determinant among Members of Enterobacteriaceae. Antimicrob. Agents Chemother., 59 (6): 3290-3297.

Xue-qing, Z., Dan-ping, L., Chun-quan, X., Min-jie, M., Shu-ying, C., Chun-chan, L., Fang-you, Y., and Liang-xing, W.2014. Detection of plasmid-mediated quinolone resistance determinants in clinical non-fermentative bacteria and ciprofloxacin sensitive Enterobacteriaceae strains. Dis. Surveillance, 29 (2): 130-135.

Yamane, K., Wachino, J., Suzuki, S., Kimura, K., Shibata, N., Kato, H., Shibayama, K., Konda, T., and Arakawa, Y. 2007. New plasmid-mediated fluoroquinolone efflux pump, QepA, found in an Escherichia coli clinical isolate. Antimicrob. Agents Chemother., 51: 3354-3360.

\section{How to cite this article:}

Mohammed A. Saleh and Mohammed M. Balboula. 2017. Plasmid Mediated Quinolone Resistance Determinants among Nosocomial Clinical Pseudomonas aeruginosa Isolates. Int.J.Curr.Microbiol.App.Sci. 6(1): 42-50. doi: http://dx.doi.org/10.20546/ijcmas.2017.601.006 